\title{
Research Square

\section{Analysis of Factors Influencing Coal Prices Under the New Normal of China's Economy}

\author{
Yang LI \\ China University of Mining and Technology \\ Haozhou CHENG (D 17338105436@163.com) \\ China University of Mining and Technology-Beijing \\ Yuqi REN \\ China University of Mining and Technology-Beijing

\section{Kunpeng YANG} \\ China University of Mining and Technology-Beijing
}

\section{Original article}

Keywords: Coal price, the new normal of economy, VEC model, supply-side structural reform, energy structure

Posted Date: August 26th, 2020

DOI: https://doi.org/10.21203/rs.3.rs-53435/v1

License: (-) (1) This work is licensed under a Creative Commons Attribution 4.0 International License. Read Full License 


\section{Abstract}

Background: After China's economy entered a new normal, the economic growth slowed down, energy market demand shrank, and the coal industry suffered from serious overcapacity. In this context, the Chinese government carried out supply-side structural reform and implemented a series of policies to cut overcapacity and destocking.

Methods: By using time series data, this paper establishes vector error correction model, combined with Granger causality test and variance decomposition, to study the factors influencing coal prices under the new normal of economy.

Results: The empirical results show that under the new normal of the economy, coal social inventory, oil production and natural gas production have a greater impact on the coal price, while coal consumption and raw coal production have a smaller impact on the coal price. According to the analysis, at the present stage, fossil energy, especially coal, occupies too high proportion in China's energy structure, which can no longer meet the requirements of energy use under the new normal of economy.

Conclusion: According to the empirical results and analysis, the Chinese energy structure must be adjusted. In the short term, supplyside structural reform policies must be deepened to change the status quo of China's coal industry as soon as possible. In the long run, non-fossil energy technologies should be vigorously developed to provide stable and cheap non-fossil energy, thus reducing the use of fossil energy and increasing the use of non-fossil energy.

\section{Background}

Since the "reform and opening up", China's economy has developed rapidly, and coal has played a crucial role in the stage. Coal has been playing a dominant role in the energy production and consumption structure, because the resource endowment is "rich in coal, poor in oil and poor in gas" in China(Guo, X. P., et al.,2016). In 2018,as shown in Fig1, raw coal accounted for 69 \% of China's energy output, and coal consumption accounted for $59 \%$ of total energy consumption. In recent years, due to the impact of environmental problems, the optimization of energy structure has been accelerated in China, and the proportion of coal in the energy consumption structure is slowly decreasing. However, at present, there is no effective alternative to coal, so the dominant position of coal in energy structure will not change in a short time.

Fig1: The structure of China's energy consumption (left)and production(right) in 2018

Since 2012, China's economic growth rate had been declining at 7.7\%, 7.7\% and 7.4\% for three consecutive years. In the first three quarters of 2015 , the growth rate dropped below $7 \%$.The weakness of the international economy, the normal contraction of external demand, the slowing growth rate of emerging economies, the obvious lack of demand-side support for the economy and the great downward pressure on the economy, all indicated that the Chinese economy had entered a new normal(Cheng,2015, Freeman,2017, Groenewold,2018). The coal industry is in the upper reaches of the national economic structure, and the whole coal industry has been greatly affected after entering the new normal of the economy. The most obvious is that coal prices were plummeting, which has left the industry in trouble(Wang and Li,2017). This in turn seriously affected all downstream industries(Xiao, et al.,2018).

In order to study the fluctuation of coal price under the economic new normal, we need to understand the formation mechanism of coal price. The mechanism of coal price formation is a complicated system, which involves the relationship between the pricing subjects and the factors of price formation, and has a great influence on the coal price. It can be seen that the formation of coal price is a very complex process that integrates various demands and considers various information. Since the founding of new China, China's coal price formation mechanism has gone through several stages, each of which is formed under the background of special social environment and has its special significance. The first phase, from 1950 s to 1984 , the coal price formation mechanism was single track system. Under the planned economy system, coal production and sales plans were basically formulated and executed by the government, so the price of coal was naturally determined by the government, and the coal price at this time had no practical significance. The second stage was from 1985 to 1992, when the coal price formation mechanism became a double track system. During that period, the main coal price was set by the government, but some coal was allowed to be priced according to market supply and demand. There were multiple levels of coal prices during that time(Yang, et al.,2018). In the third stage, from 1993 to 2005 , the coal price formation mechanism gradually began to transition from being determined by the government to coal price marketization. First, the price of non-electric coal was liberalized, then in 2002, the price of electric coal was liberalized(Zhang and Zhao,2010). Since then, the coal industry rose rapidly, the coal industry entered the beginning of the "golden decade". However, the coal price during that 
period was highly volatile. The fourth stage was from 2006 to present, when the price of coal was removed from government control and the price was determined by the market.

After the marketization of coal price, the government did not intervene in the coal price in the market, and the coal price was completely determined by the market. In the following years, China's coal industry enjoyed an unprecedented boom and entered a "golden decade". Coal demand, coal supply, and coal prices had all skyrocketed, and the industry had made tremendous progress in these years. But after 2012, the coal market got worse and worse. Due to the rapid expansion of production capacity in previous years, the entire coal market had a serious excess capacity and huge coal stockpiles. By 2015 , the loss of the coal industry reached more than $90 \%$, and the production and operation of a large number of coal enterprises were affected in China.

In this background, the Chinese government has introduced a series of policies to carry out supply-side structural reform(Cao and Dong,2018). The following measures have been implemented in the coal industry: first, in order to curb the continuous increase of production capacity from the source, the expansion of production capacity is resolutely restrained, the construction of new production capacity projects is strictly prohibited, and the construction of new production capacity is no longer approved in principle. Secondly, in order to improve the utilization rate of resources and reduce disorderly competition in the market, illegal production capacity was cleaned up and rectified, and backward production capacity was eliminated. In addition, the structure of the energy industry has been adjusted and optimized, and energy companies are encouraged to carry out mergers and reorganizations to reduce costs and expand demand to reduce overcapacity.

After several years of supply-side reform, coal stocks have been gradually reduced, and coal prices have gradually become stable, the coal industry has been out of trouble. However, it can be seen from the fluctuation of coal price that there are still a series of problems in the coal industry and even the whole energy industry, the most prominent problem is the unreasonable energy structure, coal in the energy structure accounted for too high. Under the new normal, coal prices have experienced sharp fluctuations, but unlike in the past, the consumption demand for coal has not increased due to the decline in coal prices, and the consumption demand for natural gas and oil has not decreased due to the decline in coal prices. This paper tries to discuss the problems existing in the coal and energy industry from the perspective of the factors affecting the coal price under the new normal of the economy.

\section{Literature Review}

Coal is one of the most important energy sources in the worldwide and plays an irreplaceable role in the development of human society. The price of coal affects every aspect of human life. Every time the price of coal changes, it will have a wide range of impacts. Therefore, coal price is also the focus of many scholars. It can be seen that many scholars have done a lot of research in this field.

In the study of factors affecting coal prices, Fan et al. (2019) used the Detrended Cross-Correlation Analysis method to analyze the relationship between coal and carbon prices in both time and time-scale interval perspectives. Guo et al. (2016) studied coal prices from 2012 to 2017 through five factors: economy, supply, demand, substitutes and port inventory, using the method of system dynamics. The results show that under the combined influence of these five factors, coal prices will continue to decline and will not rebound in the short term. Li et al. (2017) used econometric methods to study the relationship between coal prices and natural gas prices on the international market. Kaufmann and Hines (2018) studied the impact of natural gas on coal prices after the use of electricity generation in the United States by using vector autoregression model and using data between January 1991 and February 2016. Mohammadi (2011) looked at the long-term relationship and short-term dynamics between the three main energy prices of coal, natural gas and crude oil in the United States and found that coal prices are largely determined by long-term contracts. Batten et al. (2019) identified the Australian coal market as the dominant force in determining world coal prices, followed by Mozambique and South Africa. While China is a major source of volatility in the global coal market, it is relatively insignificant in terms of price transmission. Through the data of China thermal coal price index from January 2010 to October 2013, Kai et al. (2014)analyzed the influencing factors of China's coal price. The results showed that international oil price, coal import and export volume and other factors had no significant influence on the coal price. Ding et al. (2017) established a system dynamics model that affects the fluctuation of coal prices. The results show that coal prices will first decline and then rise in the future, and the supply and consumption of coal will show the same changing trend. The gap between coal supply and demand is very small, and the market is basically in equilibrium.

In addition, there is much literature on the interrelationship between coal prices and other factors. Chen (2014) studied the impact of coal price fluctuations on China's economy by using a non-competitive input-output model based on the fluctuations of coal prices in

Page $3 / 14$ 
China from 2007 to 2011.From the perspective of market forces, Cui and Wei (2017) used economic theory modeling and empirical cointegration analysis to find that the main reason for the distortion of coal prices is the imbalance of market forces between the coal industry and the thermal coal power generation industry. Ding et al. (2016) established the VAR model, co-integration test and timevarying variable state space model, studied the relationship between the fluctuation of China's coal price and the change of fluctuation effect, and analyzed the impact of coal price fluctuation on China's macro economy. Using econometric methods, Ding et al. (2011) analyzed the impact of coal prices on CPI and found a long-term equilibrium relationship between China's coal prices and CPI. Hou and Yang (2016) used the nonlinear regression lag distribution model to study the asymmetric effect of coal prices on China's economy, and the results showed that coal prices had a strong asymmetric effect on China's macro economy. Through the autovector regression model, granger test and impulse response, Song et al. (2016)studied the impact of coal price changes on inflation in China. Zhang et al. (2019) used the generalized matrix method to study the relationship between coal price fluctuation and price policy. Guo et al. (2016) established a quantitative regression model to study the relationship between China's coal price and the overall price level by analyzing the asymmetric impact of coal price fluctuations on the economy. The results show that the negative impact of coal price fluctuations on inflation is greater than the positive impact. By studying the price elasticity of coal demand in China's provinces, Burke and Liao (2015) found that it had been increasing since 2012,they also suggested that eliminating subsidies for coal consumption would reduce coal consumption and associated emissions by $2 \%$. Based on a computable general equilibrium model, He et al.(2010) studied the impact of coal price changes on the power sector, and further on China's macro economy. In order to study the Chinese government's response to coal price changes, Liu et al.(2013) adjusted the electricity price of industrial users and residents, and established an error correction model. The results showed that there was a long-term relationship between coal price and electricity price, but it was relatively weak. Through the key aspects of coal price formation in Poland and the national coal market, Andrzejewski et al. (2019) studied the impact of coal price changes on electricity price formation, as well as the environmental costs caused by coal use. Zhao et al. (2016) studied the price fluctuations of thermal coal through the multifractal trend volatility analysis (MFDFA).Yang (2012) established the input-output linear programming model to calculate the shadow price of coal in China based on the data from 1987 to 2007, and calculated the shadow price of coal in the coal industry at different development rates through scenario analysis. Using a system dynamics approach, Wang et al. (2017)found that the decline in coal prices had a negative impact on the overall economic development of coal chemical industry, but promoted the development of non-resource industries.

The above scholars' papers are of great significance and value. However, after entering the new normal of economy, China's energy industry, especially China's coal industry, has undergone great changes, and the influence of various factors on coal prices has also changed. And few scholars have studied the influence factors of coal price after the new normal of economy. This paper starts from the influence factors of coal price in the energy industry and discusses the influence factors of coal price under the new normal of economy, and then analyzes the existing problems in China's energy industry and puts forward the policy suggestions for improvement.

This paper is structured as follows: Section 3 provides data information, modeling and methodology. Section 4 is devoted to the empirical results. Section 5 presents some relevant discussions. Section 6 concludes with conclusion and policy implication.

\section{Data And Methods}

\subsection{Data}

This paper studies the impact of coal prices under the new normal of the economy, and mainly studies the factors influencing coal prices in the whole energy industry. Considering the validity and availability of data, the following indicators are selected for the study. Qinhuangdao port closing price of Shanxi optimal mixed coal(Q5500)(P) is selected, other indicators are the raw coal production (CP), the coal consumption (CC), coal imports (Cl), the coal exports (CE), social coal stocks (CS), crude oil output (OP), crude oil imports (OI) and the gas production (GP).These data are all monthly data from June 2013 to June 2019. The data are from the Qinhuangdao coal price network, the National Bureau of Statistics of China, and the REESST industry database. The missing data are supplemented by the average of the data of adjacent months.

\subsection{VEC model}

Engle and Grange combined the co-integration theory with the error correction model to establish the vector error correction(VEC) model. As long as there is a co-integration relationship between variables, the error correction model (ECM) can be derived from the autoregressive distribution model. However, each equation in the vector autoregression (VAR) model is an autoregressive distributed 
lag model, so VEC model can be considered as a VAR model with co-integration constraints. According to the co-integration equation, the VEC model can be expressed as Eq(1):

$$
\Delta y_{t}=\alpha \beta^{\prime}+\sum_{i=1}^{p-1} \Gamma_{i} \Delta y_{t-i}+\varepsilon_{t}
$$

where $\Gamma_{i}=-\sum_{j=i+1}^{p} \Pi_{j} . \Delta y_{t}$ is the stationary value after difference transformation, $\alpha$ is the coefficient vector, $\beta$ is the co-integration vector, $\varepsilon_{t}$ is the random disturbance term.

The above expression can also be expressed as Eq(2):

$$
\Delta y_{t}=\alpha \mathrm{ecm}_{t-1}+\sum_{i=1}^{p-1} \Gamma_{i} \Delta y_{t-i}+\varepsilon_{t}
$$

Each of the above equations is an error correction model. Where is the error correction term, reflecting the long-term equilibrium relationship between variables. The coefficient reflects the rate at which variables are adjusted to equilibrium when they deviate from the long-term equilibrium. The coefficients of difference terms as explanatory variables reflect the influence of short-term fluctuations of variables on short-term changes as explanatory variables.

\section{Empirical Results}

\subsection{Sequence stability test}

For the time series, before the establishment of the model, the stationarity test is firstly carried out for each variable sequence. In this paper, the Augmented Dickey Fuller (ADF) test method is adopted to carry out the unit root test for each sequence.

The results are shown in the Table 1. It can be seen that when the first difference is made for all variables, all sequences reject the null hypothesis at the significant level of $5 \%$. Therefore, it can be concluded that all the time series are single-order integral sequences, and the co-integration relation test can be conducted for variables.

Table 1: Results ADF unit root test

\begin{tabular}{|llllllll|}
\hline Variables & ADF Test Statistic & Prob & Results & Variables & ADF Test Statistic & Prob & Results \\
\hline P & -0.135322 & 0.6335 & unstable & DP & -7.904807 & $0.0000^{*}$ & stable \\
\hline CP & -6.073856 & $0.0000^{*}$ & stable & DCP & -12.60852 & $0.0000^{*}$ & stable \\
CC & -4.929950 & $0.0001 *$ & stable & DCC & -10.44614 & $0.0000^{*}$ & stable \\
\hline CS & -1.007333 & 0.3172 & unstable & DCS & -6.888365 & $0.0000^{*}$ & stable \\
\hline OP & -2.496652 & 0.3288 & unstable & DOP & -2.566435 & $0.0110^{* *}$ & stable \\
\hline GP & 4.717350 & 1.0000 & unstable & DGP & -8.228740 & $0.0000^{*}$ & stable \\
\hline Cl & -5.480379 & $0.0000 *$ & stable & DCl & -9.811221 & $0.0000^{*}$ & stable \\
\hline CE & -6.280936 & $0.0000 *$ & stable & DCE & -7.602765 & $0.0000^{*}$ & stable \\
\hline OI & -9.524977 & $0.0000 *$ & stable & DOI & -9.709297 & $0.0000 *$ & stable \\
\hline
\end{tabular}

Notes: D presents the first difference of variables; $* \star \star$ indicates $10 \%$ significant level; $* \star$ indicates $5 \%$ significant level; * indicates $1 \%$ significant level.

\subsection{Co-integration test analysis}

If the time series is not stationary, constructing the model directly may lead to the phenomenon of false regression. Therefore, it is necessary to use the co-integration analysis method to verify whether the causal relationship described by the regression equation is 
false regression. To determine whether a group of linear combinations of non-stationary time series have a co-integration relationship, that is, whether there is a long-term equilibrium relationship between variables. The basic condition for the existence of a cointegration relationship is that time series must be unstable, and all of them are of the same order. The co-integration test mainly includes EG measurement step method and Johansen co-integration test method, and the Johansen co-integration test method is adopted here. The co-integration relationship is determined by the characteristic root-trace test statistics.

Table 2: Results of Johansen cointegration test (Trace)

\begin{tabular}{|c|c|c|c|c|}
\hline Hypothesized & Eigenvalue & Trace & 0.05 & Prob** \\
\hline No.of CE(s) & & Statistic & Critical Value & \\
\hline None* & 0.840005 & 396.7909 & 197.3709 & 0.0000 \\
\hline At most $1^{*}$ & 0.781052 & 272.1732 & 159.5279 & 0.0000 \\
\hline At most $2^{\star}$ & 0.589590 & 168.8865 & 125.6154 & 0.0020 \\
\hline At most $3^{\star}$ & 0.441805 & 108.3258 & 95.75366 & 0.0051 \\
\hline At most 4 & 0.351361 & 68.67860 & 69.81889 & 0.0614 \\
\hline At mos & 0.278376 & 39.24283 & 47.85613 & 0.2507 \\
\hline At most 6 & 0.130979 & 17.05774 & 29.79007 & 0.6358 \\
\hline At most 7 & 0.101666 & 7.511388 & 15.49471 & 0.5190 \\
\hline At most 8 & 1.003243 & 0.220867 & 3.841466 & 0.6384 \\
\hline
\end{tabular}

Notes: The Prob** means MacKinnon-Haug-Michelis P values and * denotes that the null hypothesis of a unit root is rejected at the 5\% significant level

The results are shown in Table2. According to the results of the Johansen co-integration test, it can be obtained that, under the significant level of $5 \%$, there are 4 co-integration relationships between these variables, and VEC model can be established for further analysis.

\subsection{VEC model results}

The VEC model results are shown in Table 3 and Eq (3). In the long run, coal consumption, imports and exports will have no impact on coal prices. Raw coal production and crude oil imports will have a positive impact on coal prices, that is, as raw coal production and crude oil imports increase, coal will increase. The negative impact of coal social inventory, natural gas production and crude oil production on coal prices is that the coal price will decline with the increase of coal social inventory, natural gas production and crude oil production.

Table 3: The long run relationship of VEC model results

\begin{tabular}{|c|c|c|c|c|c|c|c|c|c|c|}
\hline Cointegrating & $P(-1)$ & $\operatorname{CC}(-1$ & $\mathrm{CE}(-1)$ & $\mathrm{Cl}(-1)$ & $\mathrm{CP}(-1)$ & $\operatorname{CS}(-1)$ & $\mathrm{GP}(-1)$ & Ol(-1) & $\mathrm{OP}(-1)$ & C \\
\hline \multirow[t]{2}{*}{ CointEq1 } & \multirow[t]{2}{*}{1.0000} & \multirow[t]{2}{*}{0.0000} & \multirow[t]{2}{*}{0.0000} & \multirow[t]{2}{*}{0.0000} & -0.0040 & 0.1003 & 10.4423 & -0.1394 & 0.1823 & \multirow[t]{2}{*}{-1927.726} \\
\hline & & & & & $(-0.4737)$ & 5.0392 & (5.7679) & $(-2.7593)$ & $(0.4754)$ & \\
\hline \multirow[t]{2}{*}{ CointEq2 } & \multirow[t]{2}{*}{0.0000} & \multirow[t]{2}{*}{1.0000} & \multirow[t]{2}{*}{0.0000} & \multirow[t]{2}{*}{0.0000} & 0.4314 & -0.6814 & 85.1845 & -1.1012 & 26.8773 & \multirow[t]{2}{*}{-89673.57} \\
\hline & & & & & $(1.5618)$ & $(-1.0427)$ & $(1.4330)$ & $(-0.6638)$ & $(2.1354)$ & \\
\hline \multirow[t]{2}{*}{ CointEq3 } & \multirow[t]{2}{*}{0.0000} & \multirow[t]{2}{*}{0.0000} & \multirow[t]{2}{*}{1.0000} & \multirow[t]{2}{*}{0.0000} & -0.0732 & -0.0578 & 3.8080 & -0.0620 & 1.0345 & \multirow[t]{2}{*}{61.7661} \\
\hline & & & & & $(-4.6213)$ & $(-1.5423)$ & $(1.1166)$ & $(-0.6510)$ & $(1.4326)$ & \\
\hline \multirow[t]{2}{*}{ CointEq4 } & \multirow[t]{2}{*}{0.0000} & \multirow[t]{2}{*}{0.0000} & \multirow[t]{2}{*}{0.0000} & \multirow[t]{2}{*}{1.0000} & -1.6568 & -1.6786 & -31.7376 & 2.6580 & 39.4663 & \multirow[t]{2}{*}{-17447.69} \\
\hline & & & & & $(-6.2399)$ & $(-2.6721)$ & $(-0.5554)$ & $(1.6668)$ & $(3.2620)$ & \\
\hline
\end{tabular}


In the short term, it is can be seen in the Eq (3), the error correction term coefficient is negative, indicating that the error correction mechanism is consistent with the error correction mechanism, and the error will return to the equilibrium state at a faster speed after it deviates from the long-term equilibrium in a short term. In the short term, coal consumption will have a significant impact on coal prices, but to a very small degree. Coal exports and crude oil imports do not have a significant impact on coal prices. The social stocks of coal will have a positive to negative impact on the price of coal. Natural gas production and crude oil production will have a positive impact on coal prices, and the impact will be large. Raw coal output and raw coal import will have negative and positive effects on coal price respectively, and the impact range will be relatively small.

$$
\begin{aligned}
& D(P)=\underset{-3.542096}{0.535947 E C M 1} \underset{-3.57586}{0.016868 E C M} 2+\underset{2.19598}{0.53888} E C M 3-\underset{-2.75551}{0.039047 E C M} 4+\underset{1.16154}{0.239037}(D P(-1))-0.227737(D P(-2))
\end{aligned}
$$

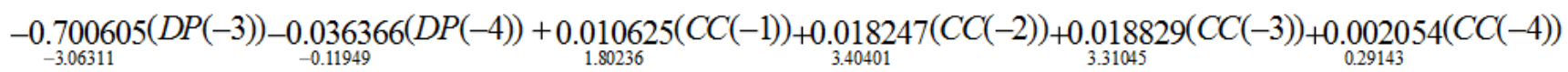

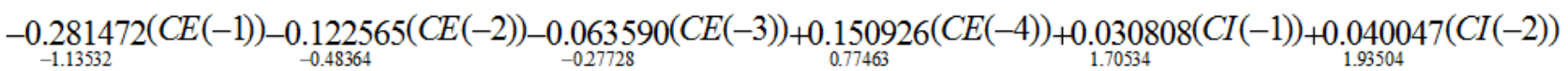

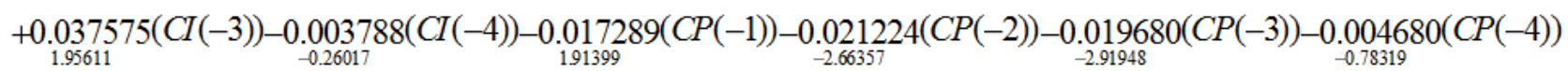

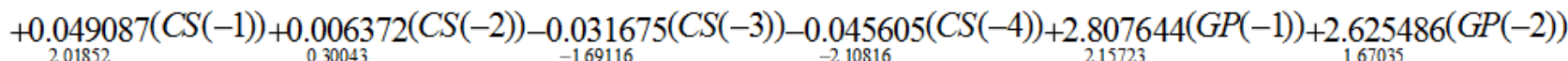

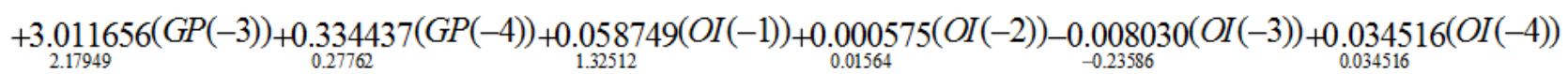

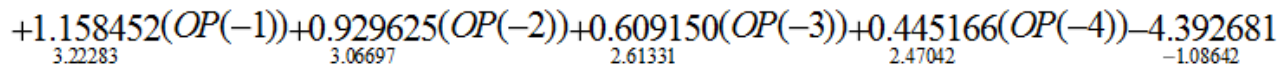

\subsection{Grange causality test}

Grange causality test is essentially to test whether the lagged variables of one variable can be introduced into the equation of other variables. If a variable is later affected by other variables, it is said that there is a Grange causality between them.

Table 4: The VEC model Granger causality test

\begin{tabular}{|llll|}
\hline \multicolumn{4}{|l|}{ Dependent variable :D(P) } \\
\hline Excluded & Chi-qs & Df & Prob \\
\hline D(CC) & 17.79008 & 4 & $0.0014^{\star}$ \\
\hline D(CE) & 2.940136 & 4 & 0.5679 \\
\hline (Cl) & 13.50939 & 4 & $0.0090^{\star}$ \\
\hline (CP) & 10.68510 & 4 & $0.0303^{\star \star}$ \\
\hline (CS) & 12.03389 & 4 & $0.0171^{\star \star}$ \\
\hline$D(G P)$ & 9.008979 & 4 & $0.0609^{\star \star \star}$ \\
\hline$D(O I)$ & 10.71410 & 4 & $0.0300^{\star \star}$ \\
\hline$D(O P)$ & 10.92092 & 4 & $0.0275^{\star \star}$ \\
\hline All & 56.99555 & 32 & $0.0042^{\star}$ \\
\hline
\end{tabular}

Notes: * indicates significant at $1 \%$; ** indicates significant at $5 \%$; *** indicates significant at $10 \%$.

According to the results of Grange test, $D(C C)$ and $D(C l)$ are the Granger causes of $D(Y)$ at the significance level of $1 \%$. At the significant level of $5 \%, D(C P), D(C S), D(O I)$ and $D(O P)$ are the Granger causes of $D(Y)$. At the significant level of $10 \%, D(G P)$ is the Granger cause of $D(Y)$.

\subsection{Variance decomposition}


Variance decomposition is used to describe the relative importance of impacts of various variables in the VAR model to the dynamic change of system variables. The main idea is to decompose the prediction mean variance of the system into the contribution rate constituted by the impact of itself and other variables according to its causes, so as to understand the relative importance of impacts of various variables to the endogenous variables of the model. The contribution of each variable to the variance of coal price was investigated, and the lag period was set as 30 . The result is shown in the figure.

From the results of variance decomposition, it can be seen that in the first phase, the explanatory power of coal prices was $100 \%$. With the advance of time, the explanatory of coal prices to coal prices gradually declined, while the explanatory of other factors to coal prices gradually increased. In the eighth cycle, coal prices had fallen to $24 \%$ of their explanatory, while other factors had contributed a total of nearly $76 \%$. Around the 20 th period, the explanatory of each variable gradually stabilized and remained unchanged. Coal prices accounted for about $24 \%$, coal stocks accounted for about $27 \%$, natural gas production accounted for about $20 \%$, oil production accounted for about $11 \%$, and other factors accounted for a total of $18 \%$.

Table 5: The variance decomposition of $\mathrm{P}$

\begin{tabular}{|c|c|c|c|c|c|c|c|c|c|}
\hline Period & $\mathrm{P}$ & CC & CE & $\mathrm{Cl}$ & $\mathrm{CP}$ & CS & GP & Ol & OP \\
\hline 1 & 100.0000 & 0.000000 & 0.000000 & 0.000000 & 0.000000 & 0.000000 & 0.000000 & 0.000000 & 0.000000 \\
\hline 2 & 80.36801 & 5.805125 & 0.910672 & 1.876265 & 0.349756 & 2.712774 & 5.787761 & 0.072153 & 2.117489 \\
\hline 3 & 62.75808 & 8.574931 & 2.203329 & 1.393288 & 0.413048 & 2.392311 & 14.65765 & 3.259115 & 4.348250 \\
\hline 4 & 45.49970 & 8.012802 & 1.756743 & 4.094604 & 0.322913 & 13.23010 & 16.24581 & 4.962758 & 5.874570 \\
\hline 5 & 35.43658 & 10.09418 & 1.159429 & 2.738451 & 1.041533 & 25.65979 & 14.32121 & 3.233524 & 6.315307 \\
\hline 6 & 32.87869 & 13.55536 & 1.398162 & 1.918404 & 1.463870 & 23.29869 & 16.93726 & 2.233882 & 6.315680 \\
\hline 7 & 27.75056 & 14.42978 & 1.593527 & 1.953936 & 1.589952 & 22.17856 & 22.89983 & 1.687695 & 5.916166 \\
\hline 8 & 24.68631 & 14.28549 & 2.628148 & 1.516861 & 1.576359 & 24.47068 & 22.92160 & 2.016881 & 5.897672 \\
\hline 9 & 24.65431 & 13.04923 & 3.301093 & 1.298451 & 1.391789 & 26.98393 & 19.97010 & 3.431878 & 5.919203 \\
\hline 10 & 24.78043 & 11.64138 & 3.384098 & 1.216567 & 1.199970 & 28.49765 & 18.67566 & 4.230781 & 6.373465 \\
\hline 11 & 25.05037 & 10.15543 & 3.331463 & 1.007145 & 1.103830 & 29.17649 & 18.24350 & 4.569873 & 7.361901 \\
\hline 12 & 25.60609 & 8.696586 & 3.377327 & 0.890735 & 1.117025 & 29.07900 & 17.50257 & 4.809743 & 8.920932 \\
\hline 13 & 25.46755 & 7.422059 & 3.333597 & 0.909102 & 1.571118 & 28.89457 & 16.96959 & 5.435859 & 9.996554 \\
\hline 14 & 25.01667 & 6.640862 & 3.319861 & 0.800260 & 1.873241 & 28.63237 & 17.23023 & 5.928469 & 10.55804 \\
\hline 15 & 24.70398 & 5.977663 & 3.179060 & 0.717390 & 1.889170 & 28.40313 & 17.91892 & 6.426419 & 10.78426 \\
\hline 16 & 24.59823 & 5.436458 & 3.007720 & 0.646555 & 1.883961 & 28.17830 & 18.39465 & 6.789526 & 11.06460 \\
\hline 17 & 24.69897 & 5.133289 & 2.851455 & 0.584943 & 1.951531 & 27.97506 & 18.64128 & 6.883552 & 11.27992 \\
\hline 18 & 24.54874 & 5.042876 & 2.734160 & 0.537472 & 2.091740 & 27.45710 & 19.13788 & 7.078356 & 11.37168 \\
\hline 19 & 24.32914 & 5.172474 & 2.625872 & 0.520574 & 2.204027 & 27.09364 & 19.68928 & 7.199000 & 11.16600 \\
\hline 20 & 24.41072 & 5.479558 & 2.595919 & 0.521273 & 2.208682 & 26.75157 & 19.90653 & 7.185717 & 10.94003 \\
\hline 21 & 24.62136 & 5.768433 & 2.613990 & 0.554655 & 2.199605 & 26.55444 & 19.76607 & 7.160616 & 10.76083 \\
\hline 22 & 24.53602 & 6.038671 & 2.669565 & 0.576716 & 2.202640 & 26.51757 & 19.69694 & 7.038019 & 10.72386 \\
\hline 23 & 24.39380 & 6.215047 & 2.736063 & 0.591897 & 2.202989 & 26.64966 & 19.56407 & 6.895071 & 10.75140 \\
\hline 24 & 24.35269 & 6.249165 & 2.800814 & 0.610605 & 2.187337 & 26.82790 & 19.36065 & 6.765451 & 10.84538 \\
\hline 25 & 24.38195 & 6.164497 & 2.837605 & 0.631286 & 2.190060 & 27.01671 & 19.19137 & 6.635291 & 10.95123 \\
\hline
\end{tabular}




\section{Analysis}

From the results of empirical analysis, coal inventory is one of the most important factors influencing the coal price under the new normal of economy. As shown in figure 2,the left axis presents the social coal stock in ten thousand tons, and the right axis presents the coal price in yuan per ton, we can clearly see the changes of coal stocks and coal price from June 2010 to June 2019, and the coal price and coal stocks almost show a reverse trend. Coal stocks fell to the lowest level in 2010, when coal prices peaked. Then coal stocks grew and prices fell. Coal stocks peaked in 2015, when prices hit rock bottom. After 2015, the supply-side reform was implemented, and coal stocks gradually decreased. On the contrary, coal prices showed an upward trend. Coal stocks have fallen to 2011 levels in 2017, while coal prices have risen to a normal level. Between 2017 and 2019, coal stocks have remained almost flat, and coal prices have fluctuated within a very small range. The results of Granger causality test show that social coal inventory is the Granger cause of coal price, while the results of variance decomposition show that after the 20th period, the explanatory power of social coal inventory to coal price reaches $27 \%$, accounting for the highest proportion among all factors in VEC model. It is well known that prices fall when stocks are large, and the results of the VEC model show that there is a long-term relationship between social coal stocks and coal prices, and that coal stocks have a negative impact on coal prices, which is also confirmed.

Figure 2: Coal price and Social coal stocks from June 2010 to June 2019

According to the results of variance decomposition, after 20 periods, the explanatory of oil production and natural gas production to coal prices is $11 \%$ and $20 \%$ respectively. Oil production and natural gas production will have a significant impact on coal prices, which is also showed by the long-term relationship of the VEC model. Oil and natural gas as alternative to coal, in general, when the supply of oil and natural gas increase, coal prices will fall, when the supply of oil and natural gas decline, coal prices will rise. However, in the new normal of the economy, the supply of oil and natural gas continues to increase and their prices remain basically stable, which is not significantly affected by the fluctuations in coal prices. This is mainly due to the structural imbalance between supply and demand of energy in China. As shown in figure 3 and figure 4, the supply of oil and natural gas has been increasing in recent years and is heavily dependent on imports. At a time when China's oil and gas demand is large and growing, the country's production of oil and gas is limited and far from meeting consumer demand. Meanwhile, coal production is high, but coal demand growth is slowing and coal stocks are huge. Under the new normal of the economy, the Chinese government is paying more and more attention to environmental problems. In order to reduce environmental pollution, it has promoted a series of measures such as "replacing coal with gas" to minimize the use of coal. For a long time, coal has been a high proportion of energy structure in China, and the development is too dependent on the use of coal, which will bring serious environmental problems, so reducing the use of coal is a choice we have to make. This structural imbalance of supply and demand will seriously threaten China's energy security.

Figure 3: Crude oil production and imports in china from 2000 to 2018 (Ten thousand tons)

Figure 4: Natural gas production and imports in China 2000 to 2018 (one hundred million cubic meters)

Moreover, according to economic theory, coal supply and demand affect coal prices. But according to the results of empirical model, the impact of coal production and consumption on coal prices is not significant. This is mainly because during the new normal economy, although the price of coal has changed a lot, the production and consumption of coal have not changed much, and basically kept the same trend. However, during that period, coal stocks were huge, so the amount of coal available for consumption was huge. Fluctuation in coal prices was basically adjusted by coal stocks, so coal production and consumption had little impact on coal prices. In order to reduce inventory, the Chinese government launched the supply-side structural reform policy. One year after the implementation of the policy, coal stocks were greatly reduced, and coal prices were basically stable, achieving good results. Now, it has shifted from reducing total coal production capacity to systematically optimizing production capacity, and the relative excess of coal production capacity will become the norm in China for some time to come. Therefore, in the short term, Chinese government still needs to deepen the supply-side structural reform urgently, in order to drive the optimization of China's energy structure.

From the above analysis, Chinese coal industry such a problem, the mail reason is about the energy structure. In 2018, coal consumption, oil consumption and natural gas consumption accounted for $59 \%, 19 \%$ and $8 \%$ of total energy consumption respectively, while other energy consumption accounted for $14 \%$. It can be seen that the three major fossil fuels account for $86 \%$, which will obviously bring serious environmental problems. That is contrary to China's economic development and energy use requirements under the new normal of economy. In order to reduce pollution and control carbon emissions, reducing the use of fossil energy is the general trend. China needs a lot of oil, but reserves and production are limited, so it relies heavily on imports. Although 
natural gas has received more and more attention in recent years, its proportion in the energy structure is still relatively low due to the limitations of reserves and transportation conditions. Therefore, to reduce the use of fossil energy, we can only start from reducing the use of coal and increase the use of non-fossil energy to meet the energy demand. Non-fossil energy accounts for only $14 \%$ of energy consumption structure, which is a very low level compared with other energy sources. The use of non-fossil energy has great room for improvement. However, the use of non-fossil energy in China is still not advanced enough to provide a stable supply in a large range for a long time. However, the advantages of non-fossil energy are obvious. Developing non-fossil energy is the best way to solve the current energy problems in China. Compared with fossil energy, non-fossil energy has the following advantages. First, non-fossil energy is cleaner. The use of fossil energy will cause a lot of environmental problems and carbon emissions, but the use of non-fossil energy can just solve this problem, which also meets the requirements of the Chinese government for energy use. Secondly, non-fossil energy is sustainable. Many non-fossil energy sources are inexhaustible in nature. Once non-fossil energy technology matures, it will ensure that China will have sustainable energy for a long time. In the future, reducing the proportion of coal in the energy structure, reducing the supply and use of coal to a reasonable level, and filling these energy supplies with non-fossil energy is the goal of China's future energy structure reform.

\section{Conclusion And Policy Implication}

In this paper, VEC model is established to study the factors influencing the coal price under the economic new normal for each time series variable. The model includes coal consumption, coal production, coal exports, coal imports, natural gas production, crude oil production and crude oil imports. It can be seen from the results of econometric analysis that these time series variables are all I(1) stationary sequences after ADF test. The results of the co-integration test show that there are four co-integration relationships between these variables at the confidence level of $5 \%$. The results of the VEC model show that coal stocks, natural gas production and oil production will have a positive impact on coal prices, coal production and crude oil imports will have a negative impact on coal prices, while other factors will not affect coal prices in the long run. In terms of short-term fluctuations, oil and natural gas production has a greater impact on coal prices.

In addition, the results of the Grange causality test show that coal consumption, coal production, coal imports, crude oil production and crude oil imports are Grange reasons for coal prices at $5 \%$ confidence level. At $10 \%$ confidence level, natural gas production is the Grange cause of coal prices, while coal exports have no causal relationship with coal prices. According to the result of variance decomposition, after 20 periods, the influence of each variable on the price of coal tends to level off. Among them, the explanatory of social coal inventory to coal price accounts for the largest proportion which is $27 \%$, followed by the explanatory power of coal price to itself , accounts for $24 \%$. And the explanatory of crude oil production and natural gas production to coal price is $10 \%$ and $20 \%$ respectively, other factors add up to $18 \%$.

After comprehensive analysis, China's coal dramatic fluctuations, mainly due to China's unreasonable energy structure. The proportion of fossil energy in the energy consumption structure is too high, especially coal, which accounts for nearly $60 \%$. The use of a large amount of coal will bring serious environmental problems, which is inconsistent with China's current energy use strategy. So, to reduce the proportion of coal in the energy structure and increase the use of non-fossil energy is the focus of energy structure optimization

Coal is still the most important energy source in China in the short term, and a large amount of coal is needed to maintain the stable development of the national economy, so the stable development of the coal industry is crucial. In the short term, the top priority is to continue to promote supply-side structural reform, continue to cut capacity and inventory, and maintain the stable development of the coal industry. From the perspective of the implementation of the supply-side reform in the past few years, coal stocks have decreased, prices have been stable, and the supply-side reform has achieved remarkable results. Therefore, in the short term, we need to continue to deepen the supply-side structural reform, deepen the market-oriented reform of coal prices, and strengthen the supervision over the production, sale and use of coal. Secondly, we should develop the technology of clean use of coal. After entering the new normal of the economy, with the transformation of China's economic structure, the demand for the environment is bound to be higher and higher. At the present stage, there are serious problems in the use of coal, and coal clean utilization technology has not been widely used. So it is very necessary to improve cleaner technologies for using coal more efficiently and environmentally friendly. Coal must be used cleanly to meet China's economic needs.

In the long run, efforts should be made to solve the problem of unreasonable energy structure. After decades of development, China's infrastructure has been basically completed, the development of energy-intensive industries has slowed down, and the driving force for development will shift from resources and low-cost labor to innovation. The role of scientific and technological growth in driving

Page $10 / 14$ 
the economic growth will continue to increase. In this context, China's coal demand will gradually decline, but overall energy demand will not decline, so the need to vigorously develop non-fossil energy. On the one hand, intensify research on the use of non-fossil fuels. At present, non-fossil energy is not widely used, the most important problem is that the technology is not good enough, resulting in the use of non-fossil energy stability is poor, and the price does not have an advantage. Therefore, to increase the proportion of non-fossil energy use, it is necessary to solve both problems. So that non-fossil energy can effectively replace the role of coal in the energy structure. On the other hand, The government should introduce relevant policies to encourage the use of non-fossil energy, for example, set emission standards for coal users, and give corresponding subsidies at the beginning of non-fossil energy use.

\section{Declarations}

\section{Ethical Approval and Consent to participate}

Not applicable.

\section{Consent for publication}

Not applicable.

\section{Availability of supporting data}

References have been provided within the "Data and Methods" section for all data used to develop this manuscript. All data are available from accessible sources and have been references. Please contact authors for any information on data sources or for actual data.

\section{Competing interests}

None of the authors have any competing interests in the manuscript.

\section{Funding}

This research was funded by the National key R \& D projects (2017YFC060300204) and Incentive funding scheme for outstanding scholars of Yueqi (800015Z1138).

\section{Authors' contributions}

Haozhou CHENG planned and conducted the analysis and prepared the manuscript. Yang LI critically reviewed the manuscript and provided valuable input with regard to co-regulation. Yuqi REN contributed to the critical reading of the draft manuscript and provided valuable input for the final manuscript. Kunpeng YANG critically reviewed the manuscript and provided valuable input with regard to the standardization. The authors rad and approved the final manuscript.

\section{Acknowledgements}

Not applicable.

\section{References}

1. Guo, X. P. ,Shi, J. X..Ren, D. F. 2016. Coal Price Forecasting and Structural Analysis in China. Discrete Dynamics in Nature and Society .Advance online publication.doi:10.1155/2016/1256168.

2. Cheng, L. 2015. China's New Normal of Economy and the Optimization and Upgrading of the Economic Structure. Proceedings of the International Conference on Logistics, Engineering, Management and Computer Science (Lemcs 2015) 117:1810-1813.doi:

3. Freeman, D. 2017. Redistributing the EU-China economic relationship: the role of domestic change in China. Asia Europe Journal 15(2):187-198.doi:10.1007/s10308-017-0474-5.

4. Groenewold, N. 2018. China's 'New Normal': How will China's Growth Slowdown Affect Australia's Growth? Australian Economic Papers 57(4):435-445.doi:10.1111/1467-8454.12121. 
5. Wang, Q..Li, R. R. 2017. Decline in China's coal consumption: An evidence of peak coal or a temporary blip? Energy Policy 108:696-701.doi:10.1016/j.enpol.2017.06.041.

6. Xiao, W. ,Pan, J. D..Liu, L. Y. 2018. China's Industrial Structure Upgrade in the "New Normal": Empirical Test and Determinants. Singapore Economic Review 63(4):1037-1058.doi:10.1142/S021759081742005x.

7. Yang, Y. Q. ,Zeng, M. ,Xue, S. ,Wang, J. Y..Li, Y. F. 2018. Unifying the "dual-track" pricing mechanism for coal in China: Policy description, influences, and suggestions for government and generation enterprises. Resources Conservation and Recycling 129:402-415.doi:10.1016/j.resconrec.2016.04.004.

8. Zhang, H. M..Zhao, G. H. 2010. A Strategy Analysis on the Price Formation Mechanism of Coal Resources. Advances in Management of Technology, Pt $1315-+$.

9. Cao, J..Dong, S. 2018. Vulnerability Analysis of Energy Supply in China. Proceedings of the Fifth International Forum on Decision Sciences 201-214.doi:10.1007/978-981-10-7817-0_19.

10. Fan, X. H. ,Li, X. X..Yin, J. L. 2019. Dynamic relationship between carbon price and coal price: perspective based on Detrended Cross-Correlation Analysis. Innovative Solutions for Energy Transitions 158:3470-3475.doi:10.1016/j.egypro.2019.01.925.

11. Guo, X. P. ,Wei, Y. N..Yuan, J. H. 2016. Will the Steam Coal Price Rebound under the New Economy Normalcy in China? Energies 9(9).Advance online pubication.dio:110.3390/en9090751.

12. Li, H. ,Chen, L. ,Wang, D..Zhang, H. Z. 2017. Analysis of the Price Correlation between the International Natural Gas and Coal. Proceedings of the 9th International Conference on Applied Energy 142:3141-3146.doi:10.1016/j.egypro.2017.12.376.

13. Kaufmann, R. K..Hines, E. 2018. The effects of combined-cycle generation and hydraulic fracturing on the price for coal, oil, and natural gas: Implications for carbon taxes. Energy Policy 118:603-611.doi:10.1016/j.enpol.2018.03.039.

14. Mohammadi, H. 2011. Long-run relations and short-run dynamics among coal, natural gas and oil prices. Applied Economics 43(2):129-137.doi:10.1080/00036840802446606.

15. Batten, J. A. ,Brzeszczynski, J. ,Ciner, C. ,Lau, M. C. K. ,Lucey, B..Yarovaya, L. 2019. Price and volatility spillovers across the international steam coal market. Energy Economics 77:119-138.doi:10.1016/j.eneco.2018.12.002.

16. Kai, Z. ,Yun, C..Yi, S. 2014. Analysis on Influencing Factors of Coal Price in China. 2014 11th International Conference on Service Systems and Service Management (Icsssm)

17. Ding, Z. H. ,Feng, C. C. ,Liu, Z. H. ,Wang, G. Q. ,He, L. Y..Liu, M. Z. 2017. Coal price fluctuation mechanism in China based on system dynamics model. Natural Hazards 85(2):1151-1167.doi:10.1007/s11069-016-2626-0.

18. Chen, Z. M. 2014. Inflationary effect of coal price change on the Chinese economy. Applied Energy 114:301309.doi:10.1016/j.apenergy.2013.09.068.

19. Cui, H. R..Wei, P. B. 2017. Analysis of thermal coal pricing and the coal price distortion in China from the perspective of market forces. Energy Policy 106:148-154.doi:10.1016/j.enpol.2017.03.049.

20. Ding, Z. H. ,He, L. Y. ,Feng, C. C..Li, W. B. 2016. The impact of coal price fluctuations on China's economic output. Applied Economics 48(24):2225-2237.doi:10.1080/00036846.2015.1117047.

21. Ding, Z. H. ,Zhou, M. H..Ning, B. 2011. Research on the influencing effect of coal price fluctuation on CPI of China. 2010 International Conference on Energy, Environment and Development (Iceed2010) 5:1508-1513.doi:10.1016/j.egypro.2011.03.258.

22. Hou, J. C..Yang, M. C. 2016. The asymmetric effect of coal price on the China's macro economy using NARDL model. 2016 International Conference on New Energy and Future Energy System (Nefes 2016)

23. Song, M. L..Wang, J. L. 2016. Coal price fluctuations in China: Economic effects and policy implications. Journal of Renewable and Sustainable Energy 8(6):Artn 065901.doi:10.1063/1.4966694.

24. Zhang, Y. F. ,Nie, R. ,Shi, X. P. ,Qian, X. Y...Wang, K. 2019. Can energy-price regulations smooth price fluctuations? Evidence from China's coal sector. Energy Policy 128:125-135.doi:10.1016/j.enpol.2018.12.051.

25. Guo, J. ,Zheng, X. Y..Chen, Z. M. 2016. How does coal price drive up inflation? Reexamining the relationship between coal price and general price level in China. Energy Economics 57:265-276.doi:10.1016/j.eneco.2016.06.001.

26. Burke, P. J..Liao, H. 2015. Is the price elasticity of demand for coal in China increasing? China Economic Review 36:309322.doi:10.1016/j.chieco.2015.10.004.

27. He, Y. X. ,Zhang, S. L. ,Yang, L. Y. ,Wang, Y. J..Wang, J. 2010. Economic analysis of coal price-electricity price adjustment in China based on the CGE model. Energy Policy 38(11):6629-6637.doi:10.1016/j.enpol.2010.06.033. 
28. Liu, M. H. ,Margaritis, D..Zhang, Y. 2013. Market-driven coal prices and state-administered electricity prices in China. Energy Economics 40:167-175.doi:10.1016/j.eneco.2013.05.021.

29. Andrzejewski, M. ,Dunal, P..Poplawski, L. 2019. Impact of changes in coal prices and CO2 allowances on power prices in selected European Union countries - correlation analysis in the short-term perspective. Acta Montanistica Slovaca 24(1):53-62.doi:

30. Zhao, Z. Y. ,Zhu, J..Xia, B. 2016. Multi-fractal fluctuation features of thermal power coal price in China. Energy 117:1018.doi:10.1016/j.energy.2016.10.081.

31. Yang, Y. 2012. Study on the Shadow Price of Coal in China. Natural Resources and Sustainable Development, Pts 1-3 361363:1285-1289.doi:10.4028/scientific.net/AMR.361-363.1285.

32. Wang, D. L. ,Ma, G. ,Song, X. F..Liu, Y. 2017. Energy price slump and policy response in the coal-chemical industry district: A case study of Ordos with a system dynamics model. Energy Policy 104:325-339.doi:10.1016/j.enpol.2017.02.014.

\section{Figures}
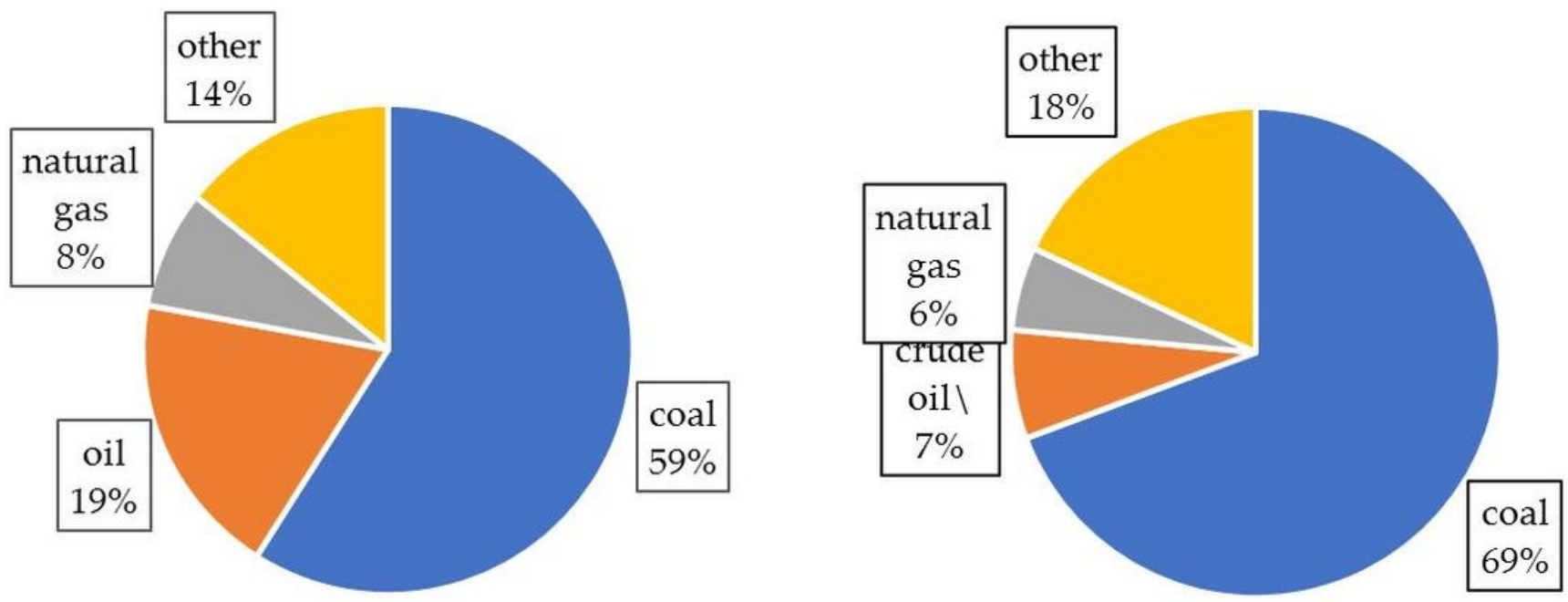

\section{Figure 1}

The structure of China's energy consumption (left)and production(right) in 2018
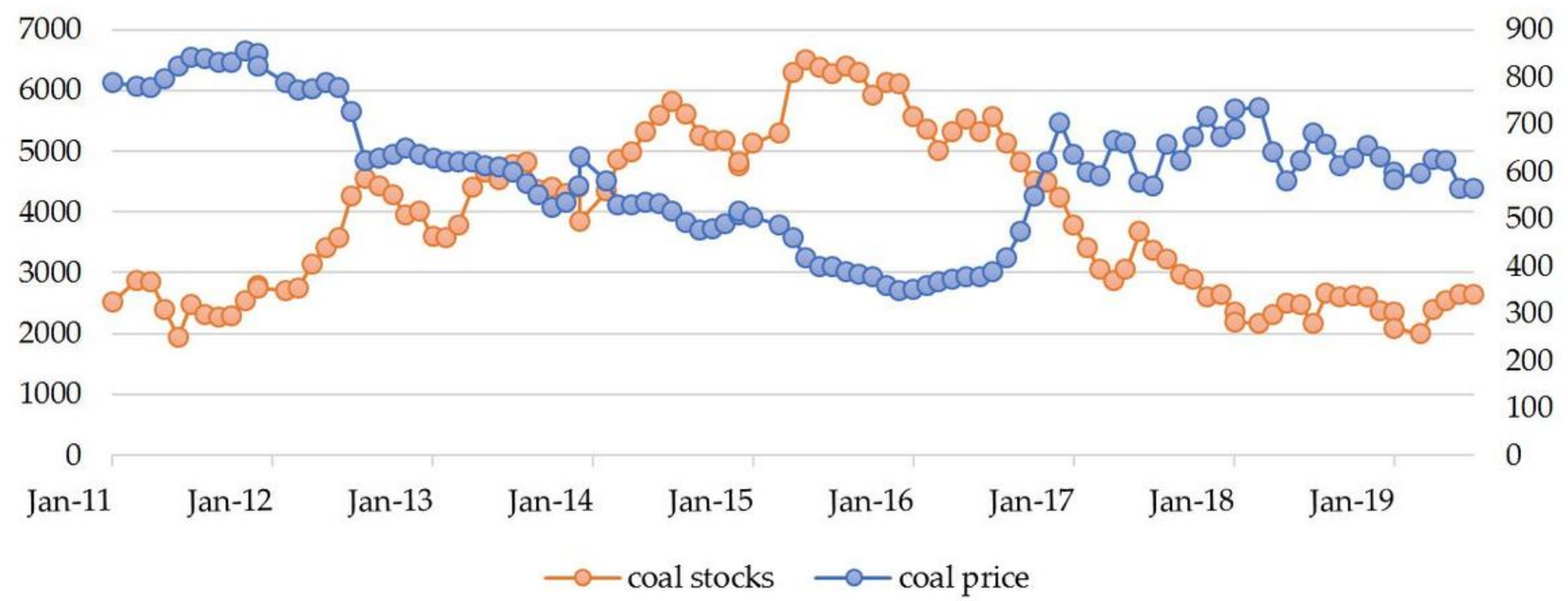

Figure 2 


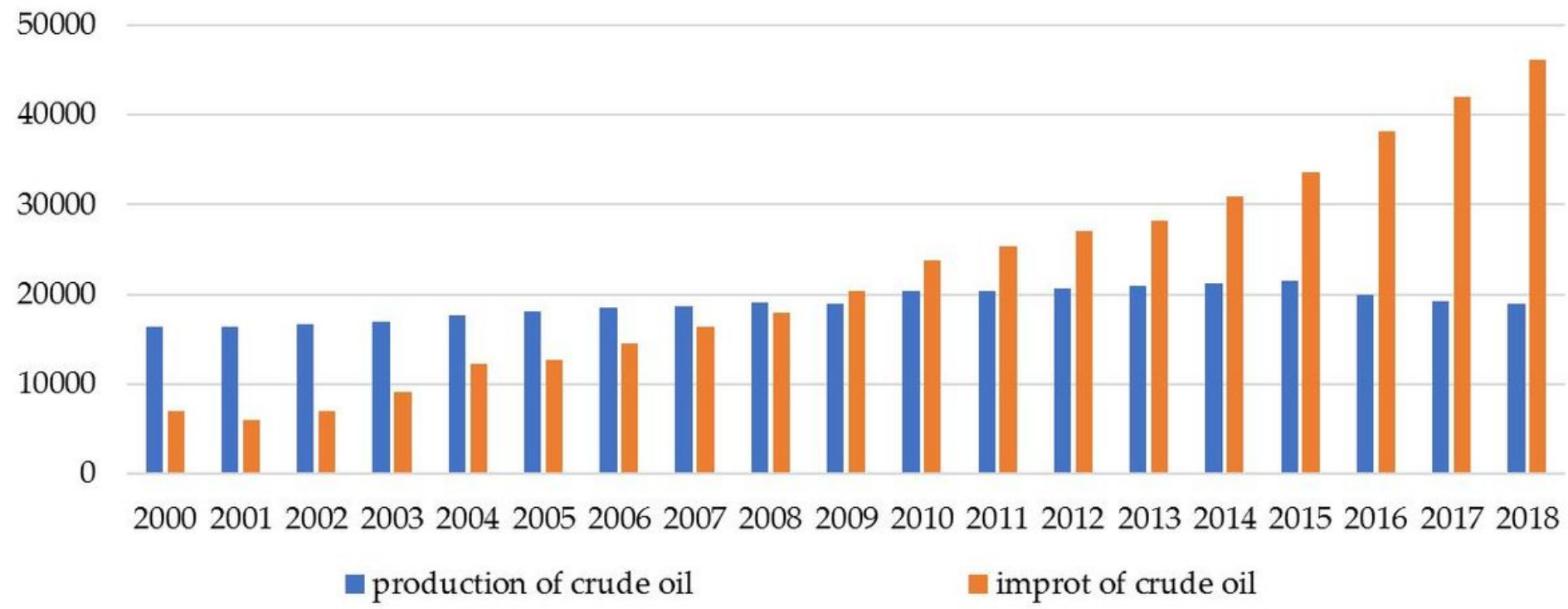

Figure 3

Crude oil production and imports in china from 2000 to 2018 (Ten thousand tons)

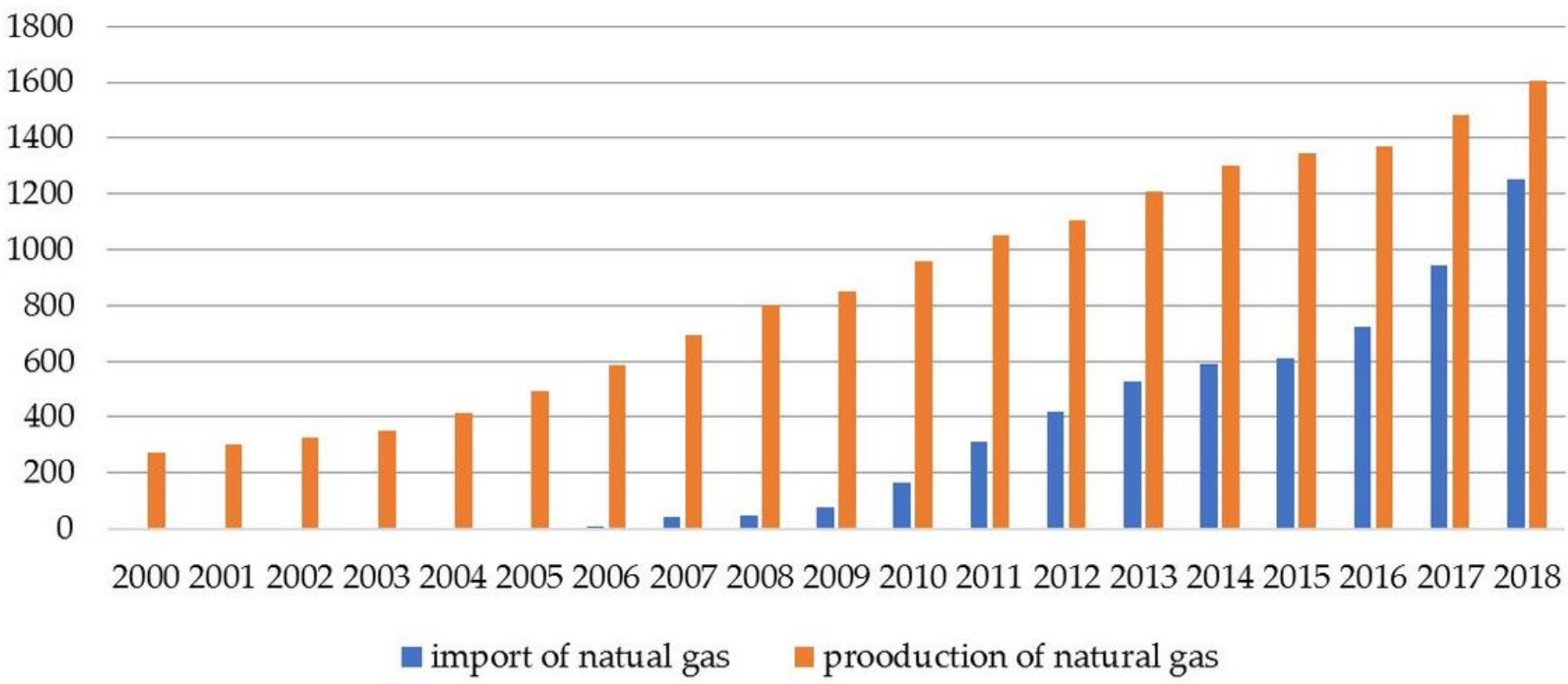

Figure 4

Natural gas production and imports in China 2000 to 2018 (one hundred million cubic meters) 